\title{
Integrating the Intercultural Communicative Competence (ICC) in a Foreign Language Program: Faculty Considerations upon Leaving the Haven of Native Speakership
}

\author{
Héctor Manuel Serna Dimas ${ }^{1}$ \\ ${ }^{1}$ Faculty of Humanities and Social Sciences, Universidad EAN, Bogotá, Colombia \\ Correspondence: Héctor Manuel Serna Dimas, Universidad EAN, Carrera 11 \#78-47, Bogotá, Colombia. Tel: \\ 57-1593-6464. E-mail: hmserna@ean.edu.co
}

Received: January 10, 2016 Accepted: February 26, 2016 Online Published: March 1, 2016

doi: 10.5539/elt.v9n4p1 URL: http://dx.doi.org/10.5539/elt.v9n4p1

\begin{abstract}
This action research study presents the perspectives of two language faculty who integrated the principles of the Intercultural Communicative Competence (ICC) model in their teaching. The professors shared their understanding of intercultural communicative competence through a learning log. These reflections were mainly about the challenged notion of native speakership, particularly in foreign language teaching contexts. The faculty also developed a teaching sequence that integrated the ICC criteria. The study offers some of the faculty considerations on their integration of the ICC model together with their students' perspectives. The research results show that students could get involved in language learning beyond the customary linguistic aspects of language teaching, and they could embark themselves upon the understanding of the intercultural aspects that permeate any classroom negotiation where two languages happen to meet and interact through the lived experiences and the identity of their speakers.
\end{abstract}

Keywords: Intercultural Communicative Competence (ICC), teaching sequence, learners' identities

\section{Introduction}

The Modern Languages program at Universidad EAN in Bogotá, Colombia aims at qualifying individuals as professionals in languages such as English, French, German, Italian, and Portuguese. The students in the program take courses in their native Spanish and English as their first foreign language, and they have two more language options to choose from among the languages mentioned before. The language qualifications these students obtain throughout their program of studies are intended to help them work with professionals in multinational companies based in the country in the areas of communications or business and finance translation.

The modern languages professors in French, English, German, Italian, and Portuguese expressed their concerns with the levels of achievement students were displaying in regards to their communicative competence in these languages; they thought their students' proficiency levels were not at the level of independent users established in the Common European Framework of Reference for Languages (Council of Europe, 2001).

The above situation was problematic for a number of reasons. First, students were learning these languages in a context where they were considered foreign so that the language encounters happened for the most part in a classroom. Second, the professors were native speakers of the languages they taught, so students viewed them, most of the time, as the only source of both language and culture. This native speaker role, to the minds of these professors, was certainly baffling since they felt that they were part of language of a culture, and to be taken as singular representatives was very suspicious to say the least! Third, the courses syllabi were filled with linguistic aspects which were for the most part grammatical in nature, and the cultural aspects were just corollaries of language aspects whose purpose was to understand the native speakers' perspectives.

These reasons seem to bear some criticisms that are not new to language teaching settings based upon the concept of communicative competence. Some of these criticisms point out that such an approach follows primarily language contents that do not make clear connections with the target language cultures they are promoting. Ju (2013) maintains that Communicative Language Teaching (CLT) in countries where a particular language is foreign will be effective to the extent that teaching takes into consideration both the cultural and educational background of the learners as well as the teaching environment teachers are to create within the 
above circumstances. Moreover, an intercultural teaching model that enacts learning must take into consideration the interchange that happens among the learner, the teaching context, and the teachers' perspectives, especially in a moment where countries are struggling with issues of diversity in the globalized world. In fact, Appadurai (1990), in his discussion of global economy and its impact on people and cultures, affirmed that "the problem of global interaction is the tension between cultural homogenization and cultural heterogenization" (p. 295).

The faculty developed an action-research project in their language courses during an academic year. One of the aims of the project was to integrate the intercultural communicative competence (ICC) model (Byram, 1997) in their lessons so that their class programs could address both the linguistic and cultural aspects of their courses. A second goal of this research project was to document the professors' process of leaving the realm of their native speakership to help students become intercultural speakers, and at the same time, to show these professors' reflections as intercultural speakers themselves. The development of these two goals is the purpose of the present article.

\subsection{Intercultural Communicative Competence}

In order for their students to start developing their global cultural consciousness, the language professors followed the model of intercultural communicative competence (ICC) proposed by Byram. The basic tenet of this model is the purposeful inclusion of the intercultural competence along with the linguistic, sociolinguistic, and discourse competences that make up the recognized definition of communicative competence. This intercultural competence will be present in the classroom in terms of what Byram defined as attitudes, knowledge, skills, and critical cultural awareness/political education (p. 57). In the realm of attitudes, the purpose is for language learners to "suspend disbelief about other cultures and belief about one's own" (p. 57). Knowledge has to do with the "knowledge of groups and their products and practices in one's own country and in one's interlocutor's country" (p. 58). Skills or "abilities to interpret an event or document from another culture, to explain it, and relate it to documents or events from one's own" (p. 61). These skills are also about the abilities to discover and interact with the interlocutor's culture in terms of attitudes, knowledge, and interpretation skills. Finally, the model requires from the learners to display their critical thinking skills since they have to "evaluate critically and on the basis of explicit criteria, perspectives, practices and products in one's own and other cultures and countries" (p. 63).

In his discussion of the planning of a curriculum for intercultural communicative competence, Byram also stresses the need for institutions to take into consideration a series of analyses based on their teaching context. For example, he mentions, "the geo-political context, the learning context, the developmental factor, the identification of objectives, and the discussion of an ICC threshold as well as a curriculum sequence" (p. 79). Although all these aspects are interconnected, both the geo-political and the learning context appear as fundamental to determine the students' needs as well as their real possibilities to interact in the languages they are learning due to the fact that these students are located in Colombia where English, French, German, Italian and Portuguese are foreign languages.

\subsection{Cultural Realism}

In regards to both the geo-political and learning contexts, people are now participating in what Kumaravadivelu (2008) calls the era of "cultural glocalization" (p. 44) which he describes as a bidirectional process where two cultures meet and influence each other. He asserts that these processes happen at different levels of society, and it requires from different institutions in society to be conscious about this situation and make it a paramount part of their endeavors.

The education of the glocalized world is better understood in terms of what Kumaravadivelu defined as "cultural realism" (p. 157) which empowers individuals to develop a sense of cultural consciousness. This consciousness or progressive levels of consciousness are only achieved when individuals assume both their native and foreign culture with critical reflective thinking. Kumaravadivelu claims that language learners need to be engaged in projects in which they constantly look at both cultures to view and understand both the positive and negative aspects they offer. To sum up, he asserts that:

The inherited culture should be freely allowed to interact with the lived culture so that there is mutual enrichment. The key to this enrichment is the lived experiences of individuals. Global cultural consciousness demands that all individuals function as self-regulating human beings capable of receiving, understanding, exchanging, and judging cultural information (p. 165).

It is interesting to see the number of coincidences between the model of intercultural communicative competence and the concept of cultural realism. First, they both doubt the ideal of native speakership that places learners in 
some sort of a quest to reach a linguistic sanctuary. Instead, both ideas maintain that language learning happens in relation between one's own culture and that of the interlocutor's. Second, they also view individuals as people who are either on the move through immigration or in contact through a number of technological resources at their disposal such as the internet, the mass media, and the popular culture. Third, they both see the need to work with language learners from a view on culture that goes beyond the concept of assimilation or transculturation. Both the intercultural communicative competence and cultural realism claim that individuals need to engage actively and critically with the world of the other culture or cultures.

\section{Action-Research Methodology}

Action-research has a very long history that can be traced back to its origins with Lewin (1952) who viewed research as a cyclical process. It is also worth mentioning the work of Kemmis and McTaggart (1988) who advanced the idea of collaborative work around curricular issues. In a similar vein, the seminal work of Stenhouse (1979) in regards to teachers' involvement in educational research has been fundamental to determine both the legitimacy and validity of action-research in educational settings. Finally, the work of Elliott (1991) cited by Altrichter, Posch, and Somekh (1993) as they hold his definition of action research as "the study of a social situation with a view to improve the quality within it" (p. 4).

The place of action-research amid the continuum of research perspectives may be understood within what Mills (2003) conceive as both practical and critical. Action research is practical since it is oriented to solve real-life problems in educational settings; it is also practical since practitioners are called upon modifying their practices based upon criteria that come from their appraisal of their work in their classrooms. The critical perspective in action research emerges when teachers become teacher-researchers. By acknowledging this new condition as researchers, teachers liberate themselves from the shackles of ready-made answers that are common currency in teacher preparation programs, in-service teacher trainings, or certification systems. Mills considers that one of the major epistemological assertions of action-research has to do with the claim that "truth is relative, conditional, and situational and that knowledge is always an outgrowth of previous experience." (p. 6).

Action-research is for the most part a spiraling cyclical process that begins by clarifying a conflicting area which eventually will become the research focus. This first moment of the cycle ends with the establishment of a research problem and research questions. Then the teacher-researcher gathers relevant information oriented towards either developing insights into the problem or looking for plausible solutions. This process may involve a literature review around the issue being studied. The next moment of the cycle is the formulation of an action-research plan which includes the problem variables, the intervention/innovation, a data collection plan, and a timeline for the intervention (pp. 46-47). The cycle continues with the intervention and the data collection moments where the teacher-researcher analyzes the data and interprets his findings against the problem area and the research questions. Finally, the researcher may end the research cycle or decide to start a new one with the findings of the first cycle which may become the baseline to further a new research cycle.

This action-research study is qualitative, and it intends to give a hermeneutic account of these professors' understanding of intercultural communicative competence and its application in the language classroom. The hermeneutic view is interested in obtaining the research participants' perspectives that are not purely opinions. In fact, these perspectives happen as dialogue which means that individuals are empowered to build particular bonds with their interlocutors. Freeman (1996) determines that the focus of this research paradigm is to gather "what people think and how they understand the worlds in which they live and act" (p. 360).

This research process began with a research seminar on intercultural communicative competence that lasted three months. The research questions that the modern languages faculty articulated as the result of their new conceptualizations of the communicative competence were the following:

- How do teachers and students make sense of the ICC model in regards to their conditions of native and non-native speakers correspondingly?

- What is the role of identity of teachers and students in the process of becoming intercultural speakers?

The next step of the cycle was the design of a language teaching sequence that purposefully integrated the components of the ICC model. The team of researchers worked on their teaching sequences for another three months. The teaching sequences were then piloted with the modern language students in Italian, German, French, English, and Portuguese. The piloting was conducted for about four months of an academic semester. Finally, the professors developed some analyses of their experiences by reading and reviewing the data they had collected in their classrooms. 


\subsection{The Research Participants}

The participants in this research project were full-time professors in the Modern Languages program. I was the leader of the project, and my job was essentially to design the action-research project and work on the research group sessions throughout the year to provide guidance on the various moments of the research cycle. The team of researchers were Salvatore (Italian), Elodie (French), Denise (Brazilian), Olaf (German), and Mario (Cuban). They were all native speakers of their languages except for Mario, a native Cuban with a high level of English proficiency.

These professors arrived in Colombia in different circumstances; however, they had been living in the country for more than five years. They all had a background in education or language teaching and ended up working in a university setting. Their arrival and initiation in tertiary education was full of challenges since they had to confront their students' local school culture with their own which for all of them caused constant misunderstandings or clashes.

The first element that drove this research process was the idea of questioning the conception of native speakers these professors had. The seminar on ICC allowed them to realize that interculturality is a two-lane road that they have to be willing to travel; however, such a trip is not always easy since languages and cultures may be both an asset and a liability depending on how people walk their paths and unpack their luggage. For example, faculty who come from European countries may have at their disposal a variety of resources to deepen their teaching of languages by infusing cultural aspects relevant to their home countries and societies. However, some of these views may take up the entire teaching context leaving out the students' perspectives on the very same issues. Moreover, language professors may think that their students need to respond in congruence to the expectations they have from their own countries and school contexts. In other words, this faculty may be working with students to help them be bilingual or multilingual, but their approach is their own monolingualism and monoculturalism.

A case in point is provided by Canagarajah (1999) who has an interesting argument for a change in the pedagogy to teach English language learners in the international milieu. He claims that English language teaching professionals tend to regard teaching as a cognitive activity limited to the classroom walls and totally detached from the larger "historical and social conditions" (p. 17) of the learners. Thus, he advances the tenets of a critical pedagogy (CP) in which teachers need to come to terms with the idea that "knowledge is negotiated rather than handed over to students in the form of established facts and rules" (p. 16). Moreover, many instances of such negotiation happen at the boundaries of the students' language, culture, and identity.

These professors wanted their students to step away from their rigid conceptions of viewing them as the only source of knowledge. Thus, their desire was to give them more agency and responsibility for their own learning. They also sought for their students to be able to put their language and culture in relation. In fact, the personal aspects that students developed in most classroom projects had to do with how they understood and questioned aspects of their lives and local culture that were intertwined with issues of identity.

Ochs' (2002) seminal research on the use of language as a vehicle for socialization provides solid evidence on how people take part in communities through socialization practices. This process is developed essentially through language and particular uses of language in specific contexts. She asserts that "four dimensions are essential to the socialization of the cultural competence: the ability to signal the actions that one is performing, the psychological stances one is displaying, the social identities one puts forward, and the activities in which one is engaged" (p.109). The above elements offer stimulating insights on how teachers and students should think of their actions in language classes. These linguistic behaviors certainly go beyond recitation drills or simulated real-life activities. Similarly, Van Lier (2002) argues for what he calls an ecological approach to language education in which teachers and learners see language as a "living entity that they need to understand in terms of what it does to whom, by whom, and for whom in the multiplexity of semiotic systems in which it (language) operates, or rather co-operates with other meaning-making processes." (p. 145).

\subsection{Data Collection Instruments}

The professors completed a learning log as a result of a number of seminar sessions on the fundamentals of intercultural communicative competence. The second moment of data collection on the professors' thinking was through their teaching sequences which were also discussed by the group of faculty. In third place, the faculty shared some of their data collection instruments by means of a reflective journal where they described their own thought processes from the beginning to the end of their experience. For the scope of the present article, the views of the English and French professors will be presented here. 


\subsubsection{Learning Logs}

The point of entry of all the professors who participated in this research was to reflect upon their own notions of what it meant to be a 'native' speaker of a language. This reflection was particularly important since all the professors were native speakers of their languages and were teaching them in a context where their languages were considered foreign languages. As a result, for many students, the language professor is the archetypal representative of a particular culture. This situation is not desirable at all since learners will be prone to homogenizing and stereotyping the culture of a language based on the judgment of one of its speakers.

Elodie, a Swiss native, who has a command of other languages such as English, German, Spanish, and Polish described succinctly how much each language meant to her, and how there were important moments in her life that were related to these languages. She asserts that:

French is my native language, and it was thanks to my mom that I developed it. She was the guardian of both the language and the culture whereas my dad who also spoke French had some influences from German because he had been raised in a German-speaking city (Learning log. p. 1).

She also claimed, for instance, that Polish was a language that she felt was very close to her feelings. In fact, she asserted in her learning log that, "when I am too excited or even tired, words come to me not in French but in Polish." (Learning log, p. 1).

Mario's learning log was more concerned on how he could put together the principles of intercultural communicative competence and the book he was following with his students. Mario's approach was much more practical in the sense that he wanted to see how he could see the intercultural communicative competence at work in his business lessons whose focus was on job interviews. In fact, his reflections on this particular matter showed that job interviews were highly sensitive to intercultural exchanges since personal and professional aspects were intertwined even when students talked about their own culture without even comparing them to another language or culture.

One of the students' feedback cards for one of his lessons shows how students felt about preparing their curriculum vitae and the interview questions.

\section{Feedback card}

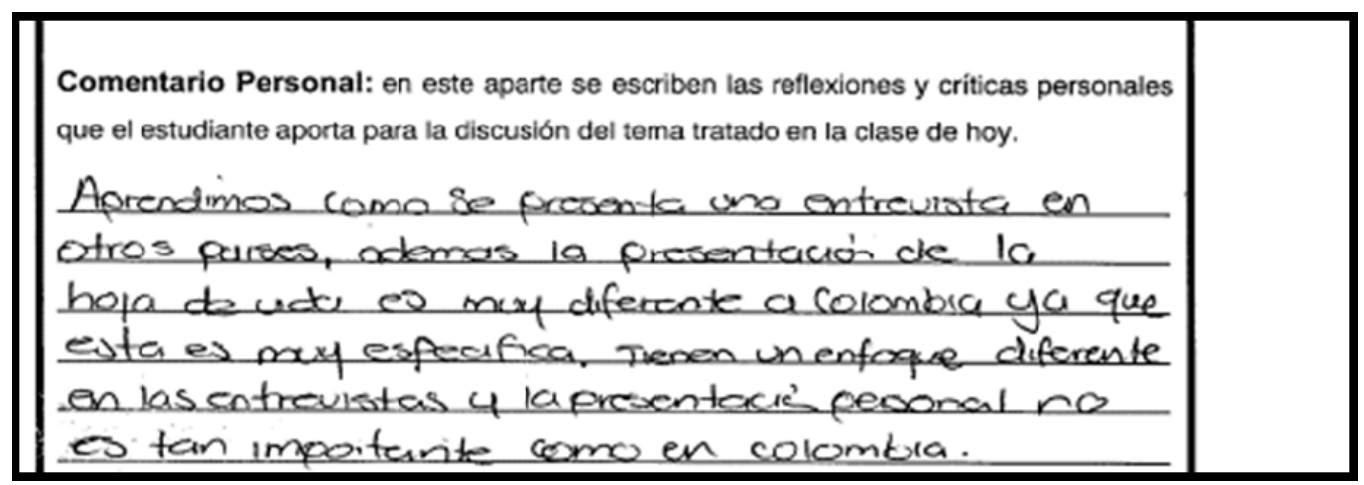

The feedback card roughly translates as follows:

We learned how to do a job interview in other countries. Besides the CV presentation is very different from the ones we do in Colombia. It is very specific. The interviews have a different approach since aspects such as your personal appearance is not as important as it is in Colombia.

The common thread that run through the professors' learning logs are related to issues of identity which are always at stake in the language learning processes. Alexandru (2012) in her discussion of the context of intercultural communicative competence points out the importance of identity in the process of intercultural learning; she asserts that:

Any subject defines himself through individual identity. It represents a set of individually selected values generally accepted by the human group. The individual manifests his identity and tests the identitary strategies by interacting with other individuals in the group he belongs to or outside it. Thus, he obtains the coordinates of his similarity to others and those of his difference towards others (p. 38). The above quote shows the relevance 
of interaction as the medium through which individuals will develop "the coordinates" that will allow them to locate their actions in a given context or a particular society. In fact, these coordinates are established for the most part on aspects of the students' self-identity, and how they make sense of the teaching context. Norton (2000) considers that identity has to be part of theories of SLA because people are immersed in a number of social interactions where issues of power, identity, and access to a speech community are based on the individuals' ability to speak, and I would say on the individuals' ability to speak up. Norton also argues that the concept of communicative competence needs to be reexamined in the sense that the classroom dynamics "should take seriously the lived experiences of language learners" (p. 139). The main reason to include the learners' experiences is related to both the recognition and the value of the learners' identities as propellers of the learning process.

\subsubsection{Language Teaching Sequence}

The second moment of data collection in the present study was based on the teachers' design of a language teaching sequence that included the main concepts of the intercultural communicative competence namely knowledge, skills, and attitudes together with some reflections and the evaluation of the process and its outcomes.

The professors met during the semester to review the key concepts around the intercultural communicative competence so that they could come up with a teaching sequence. They all agreed that a teaching sequence had to be based upon a class project whose scope was going to be around four or five two-hour class sessions. They also agreed upon a framework which included knowledge, skills, and attitudes. One of the most important aspects the professors discussed was the idea of working with language activities so that students would be able to have the vocabulary and discourse that was required to work on their projects. In order to guarantee that students had the language required to be able to participate in the project, the professors also determined the content, the language resources, and the expected outcomes of the activities.

All the research team followed the same criteria to prepare their teaching frameworks/sequences. The following chart presents the sequence designed for a course with beginning students of English.

\section{Intercultural Communicative Competence (ICC)}

\section{Lesson Template}

Language: English

Level: Basic

Theme: Career World

\begin{tabular}{|c|c|c|c|c|}
\hline SESSION & $\begin{array}{l}\text { COMPETENCE } \\
\text { COMPONENTS }\end{array}$ & CONTENT & $\begin{array}{l}\text { LAGUAGE } \\
\text { RESOURCES }\end{array}$ & $\begin{array}{l}\text { EXPECTED } \\
\text { OUTCOMES }\end{array}$ \\
\hline $120^{\prime}$ & $\begin{array}{l}\text { Knowledge } \\
\text { Criteria to select } \\
\text { and appoint new } \\
\text { personnel }\end{array}$ & $\begin{array}{l}\text { Students share ideas } \\
\text { on criteria to select } \\
\text { people for vacant jobs. }\end{array}$ & 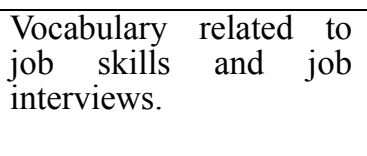 & $\begin{array}{l}\text { Students will command } \\
\text { words and expressions } \\
\text { for job interviews. }\end{array}$ \\
\hline $120^{\prime}$ & 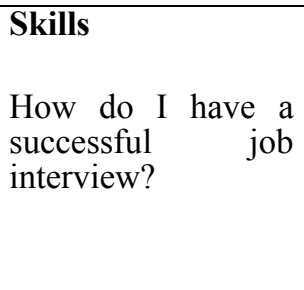 & $\begin{array}{l}\text { itch videos } \\
\text { iews. }\end{array}$ & $\begin{array}{l}\text { Students will make a list } \\
\text { of words and } \\
\text { expressions used in job } \\
\text { interviews. } \\
\text { Students pay attention } \\
\text { to the adequacy between } \\
\text { questions and answers } \\
\text { in job interviews. }\end{array}$ & $\begin{array}{l}\text { Students write down } \\
\text { the most relevant } \\
\text { questions and answers } \\
\text { in job interviews. }\end{array}$ \\
\hline $120^{\prime}$ & $\begin{array}{l}\text { Attitudes } \\
\text { Establish relevant } \\
\text { aspects of a job } \\
\text { interview }\end{array}$ & $\begin{array}{l}\text { Students role-play job } \\
\text { interviews so that their } \\
\text { classmates are able to } \\
\text { evaluate their } \\
\text { performance. }\end{array}$ & $\begin{array}{l}\text { Students } \\
\text { themselves for a job } \\
\text { interview by reviewing } \\
\text { the most relevant } \\
\text { questions and answers. }\end{array}$ & $\begin{array}{l}\text { Students are able to } \\
\text { evaluate their work } \\
\text { when they have a job } \\
\text { interview. }\end{array}$ \\
\hline $120^{\prime}$ & $\begin{array}{l}\text { Reflections } \\
\text { Compare and } \\
\text { contrast cultural } \\
\text { aspects of a job } \\
\text { interview. }\end{array}$ & $\begin{array}{l}\text { Students evaluate the } \\
\text { job interviews they } \\
\text { worked in class. }\end{array}$ & $\begin{array}{l}\text { Students determine the } \\
\text { most appropriate } \\
\text { questions and answers } \\
\text { in the job interviews. }\end{array}$ & $\begin{array}{l}\text { Students share their } \\
\text { criteria to determine } \\
\text { the most appropriate } \\
\text { job interviews. }\end{array}$ \\
\hline 5 & Evalu & $\begin{array}{l}\text { Students share the } \\
\text { evaluation they made }\end{array}$ & $\begin{array}{lcr}\begin{array}{l}\text { Students } \\
\text { criteria }\end{array} & \begin{array}{c}\text { list } \\
\text { about }\end{array} & \begin{array}{r}\text { some } \\
\text { the }\end{array} \\
\end{array}$ & $\begin{array}{l}\text { Students write } \\
\text { and submit }\end{array}$ \\
\hline
\end{tabular}




\begin{tabular}{|l|l|l|l|l|}
\hline $\mathbf{1 2 0}^{\prime}$ & $\begin{array}{l}\text { of their participation } \\
\text { in the job interviews. }\end{array}$ & $\begin{array}{l}\text { aspects to take into } \\
\text { consideration for job } \\
\text { interviews. }\end{array}$ & criteria. \\
\hline
\end{tabular}

The above language teaching sequence worked as a framework for teachers to enact their comprehension of the intercultural communicative competence. The conclusions they gathered from the implementation of these sequences could be summarized as follows:

- Students felt that even though there were both similar and dissimilar aspects in language learning, the only way to understand them was to think their languages in relational terms.

- Students were also able to think of language learning as a process in which they needed to develop the ability to abandon their comfort and certainty of concepts that they had already built in their L1/C1 and were very much taken for granted.

- Students realized that they needed to have a grasp of their L2/C2 beyond the aspects that their "native" teacher could teach them since many of the elements they encountered in class had to be researched or recontextualized on the basis of the language learning projects they pursued.

This very last conclusion is perhaps one of the most enlightening in the process of rethinking the idea of communicative competence in EFL settings. I think that students' language education needs to include research in both its philosophical and more practical terms so that students develop an inquisitive mind towards their learning together with some actual tools on how to go about this questioning. They also need to be aware of the conditions in which they are learning so that they are able to make changes, adaptations, or even reconfigurations of both their L1/L2 and C1/C2. Finally, both teachers and learners need to be seen not as native speakers but as 'cultural informants' (Kumaravadivelu, 2003) whose background, behaviors, and learning expectations are valued as legitimate input towards a new understanding of both language and culture.

\subsubsection{Reflective Journals}

What follows is the description of both the French and English teachers' classroom projects together with their thinking on how the actions they pursued allowed them to reflect on the dichotomy between the native and the intercultural speakership where issues of identity became relevant in the way students framed their learning.

\subsubsection{Childhood Memories in a French Class}

Elodie's intercultural teaching sequence was based on the reading of a book chapter of the novel "Kyra Kyralina" by Panait Istrati (1977). The main idea was to follow the development of a character named Stavro, particularly his childhood life events. The very first task students had to work on was to get familiar with the author and his home country, Romania. This was perhaps one important moment for students to reflect upon interculturalism because they were Colombians who read a book in French from the perspectives of a Romanian author.

Elodie's students did some reading comprehension sessions in which they analyzed some cultural aspects of the narrative such as beauty, food, drinks, family problems, violence. The students also did some research on these cultural aspects based on the perspective of an eastern country such as Romania to have a better understanding of the story.

Both the students' research and classroom presentations led to a discussion of their own childhood memories and how much they treasured them. The students' main task was to write an autobiographical composition about their childhood; however, they needed to pay close attention to the description of elements that were curious or strange to the reader due to cultural aspects involved which had to do mainly with their Colombian upbringing. The students' narratives in French had to comply with three criteria: students' abilities to narrate events, ability to present Colombian cultural aspects, ability to recreate personal experiences.

Elodie's comments about the students' first rendition of the narratives were focused on how little they conveyed aspects of the Colombian culture. They presented random events which did not reflect memories of their families. In fact, it was notorious how these students depicted aspects that had to do with the influence of the American culture in the lives of Colombians. For example, they talked about foods such as hot dogs and television shows such as "The Power Puff Girls".

After this first feedback on their writing, students were asked to enrich their narratives with a series of cultural criteria such as customs, traditions, expressions of love and care. Once they were given these elements, they 
worked on a revised version of these narratives which eventually provided a historic account of the students' lives. At this point, students realized that it was as important to work on the content of their narratives as it was to work on the linguistic aspects of narratives such as the use of the quintessential 'passé composé' and chronological connectors to structure narratives in French. On a second rendition of the students' writing, Elodie could actually see a much more culturally sensitive account of her students' childhood memories:

\section{Mon enfance colombienne}

Quand je pense à mon enfance, je me souviens de grands moments avec ma famille qui est de la Côte Caraibe, de nos coutumes et traditions et des jeux que $j$ 'avais avec mes amis. Pour commencer, je voudrais dire que $j$ 'ai toujours pensé que mon enfance avait fini à l'âge de 13 ans parce que, cette année-là, j'ai eu mon premier copain. J'évoquerai ici quelques faits importants dont je me souviens avec plus d'affection et de joie.

L'origine de ma famille est très importante pour définir l'essence de mon enfance, car je suis née dans les Caraibes et je me sens totalement orgueilleuse d'être de là-bas. Petite, j'avais les cheveux frisés et comme j'ai vécu à Bogotá depuis l'âge de deux ans, quand j'arrivais à Cartagena (ville de naissance de ma mère) ou Sincelejo (ville de naissance de mon père) à l'époque des vacances, mes amis me disaient: "Tu es une Cachaquita Costeña » et je ne riais pas. Je me sentais costeña sans discussion. Je dansais comme une costeña, je parlais fort comme une costeña, je marchais comme une costeña... mais je n'avais pas l'accent d'une costeña. En effet, j'ai toujours eu un accent très neutre, alors les personnes ne me rattachent pas avec ma culture, à moins que je ne parle de cela. Aujourd' hui, cela ne m'importe plus mais en temps-là, c'était très important pour moi.

In the text above, the student talks about her upbringing in which she claims that she has roots with people from the Caribbean coast of Colombia even though she was in the capital city of Bogotá. Moreover, she also acknowledges the fact that she seems to have a double life that is characterized by her identity as a person from the coast who happened to be living her childhood in Bogotá. This particular narrative is very relevant for the Colombian context where there are significant differences among the people from the coast and the people from the mountain ranges. The people from these regions display very different characteristics, behaviors, and visions of life even though they are located in the same country and share the same Spanish language.

Elodie's reflections upon the evolution of her teaching sequence shows how this project started as a customary language activity in which students had to provide a narrative of past experiences to demonstrate the use of linguistic aspects to write a short biography of their childhood years. However, the criteria that she used to frame the activity was intercultural in nature and required from students to talk about their lived experiences as children raised in Colombia. Besides that, students were also encouraged to display their critical thinking in regards to how they needed to think about their lives in terms of the circumstances and issues that had an impact on them.

\subsubsection{Understanding the Dynamics of Job Interviews}

Mario's teaching sequence was based on job interviews in English. Students were given exposure to some job interviews from which they could gather what both the interviewer and the interviewee care for in these scenarios. Students had to prepare vocabulary and language expressions to be able to talk about themselves in terms of personal information, skills, and experience. They were also given the chance to look at situational aspects in job interviews which reveal the interviewer's agenda towards this communicative event. Next, students had the opportunity to prepare themselves for job interviews so that they eventually role-played them in class. The role-play sessions were followed by students' feedback sessions on their performance. They made comments about the students' roles as either interviewers or interviewees as well as their linguistic abilities.

Mario's data collection allowed him to see how students understand the differences in the presentation of curriculum vitae and job interviews which certainly challenged their taken for granted assumptions in their $\mathrm{L} 1 / \mathrm{C} 1$. For example, job interviews in the Colombian context have a strong emphasis on the interviewee's qualifications and personal presentation whereas in the context of English- speaking countries there are other areas that are more relevant such as the candidate's job experience, expectations, or even future contributions to the company.

Mario's students were given the chance to abandon the neat textbook ideas of job interviews to reflect upon what these interviews meant for the lives and the future of people's life projects, and how they needed to face them 
taking into consideration not only their $\mathrm{L} 1 / \mathrm{C} 1$ constructs but also the new $\mathrm{L} 2 / \mathrm{C} 2$ perspectives. Thus, a language topic such as job interviews fits well within the framework of intercultural communicative competence. In fact, any topic may be treated within this framework since teachers and students will relate to any topic in both linguistic and cultural terms.

I think that the accounts of Mario and Elodie reveal unsurprisingly that negotiation of ideas in a second or third language is permeated by issues of identity as Norton points it out when she defines identity in second language learning as "how a person understands his or her relationship to the world, how that relationship is constructed across time and space, and how the person understands his possibilities for the future" (p. 5).

\section{Results}

I think that Appadurai's quote about the challenges within cultural homogenization and heterogenization encapsulates the results of this study. Teachers and students gather together in educational settings to achieve a common endeavor which is to be able communicate and interact in a particular language. However, the study of this particular language will always bring about the heterogeneity of the classroom participants. In fact, for this language learning to become a reality, teachers and students need to understand that they will always have a social identity to commit themselves because "it comprises a range of social personae, including for example, social roles, statutes, and relationships, as well as community, institutional, ethnic, socioeconomic, gender, and other group identities." (Ochs, p. 109). As a matter of fact, successful language learning is largely based upon how people are able to demonstrate such variety of roles when they interact with speakers or have access to speech communities of their target language.

Both Elodie and Mario provide insightful accounts of the growing complexity of language teaching and learning in the XXI century. Many language programs strive for developing students' abilities to be competent speakers against frameworks, standards, and tests in processes of homogenization. However, the reality of many language learning contexts is populated with students and teachers who are heterogeneous in nature and who are always exercising their identity as a fundamental part of the teaching/learning process.

The students' narratives in French and the reflections about job interviews in English showed that language teaching and learning require the inclusion of intercultural aspects where students are able to make sense of these learning experiences using criteria from their native language and culture as well as the target language and culture. Besides students need to be given opportunities to express what the class content means to them as part of their lives as learners and as human beings.

The conclusions of this research process point to the direction that it is very viable that language learning processes need to begin by establishing what Tudor (2001) conceptualized as the rationalities of the teaching/learning process "an internally coherent set of beliefs about the nature and goals of language teaching" (p. 32) The integration of the Intercultural Communicative Competence in the Modern Languages Program at Universidad EAN is intended to bring together the students, the teachers, and the institution around knowledge, skills, attitudes and critical cultural/political awareness as important elements to equip language learners with sound criteria to exert their identity in circumstances that are signaled by complex issues of diversity.

In regards to the research questions and goals of the present article, I can say that, on the one hand, these two professors integrated the intercultural communicative competence model in their lessons so that their classes addressed both linguistic and cultural aspects from the perspectives of the participants in the course. Elodie elicited childhood narratives whose content was filled with cultural references that provided sense to the students' writing. Mario's students realized the complexity of job interviews which were very much in tune with Ochs ideas about social identity. On the other hand, the research project documented the professors' process of rethinking their teaching to the light of their reflections as intercultural speakers. I think the most fundamental aspect that this faculty gathered from their classroom experience was the inclusion of students' personal aspects as important elements that led their engagement and further learning.

Finally, leaving the haven of native speakership is by no means an easy task. Teachers and students need to work towards creating what Jin and Cortazzi labeled as a "synergy model" of learning in which there is a need for "mutual understanding of different cultures, communication styles, and academic cultures" (p. 114). The scholars assert that the model does not intend to merge cultures into one; however, it is meant to make people aware of how these systems operate and appreciate the new perspectives. Furthermore, the appreciation of such perspectives takes place in the instances of language negotiation and cultural understanding that are required not only classrooms but also in societies. 


\section{References}

Appadurai, A. (1990). Disjuncture and Difference in the Global Cultural Economy. Theory Culture Society, 7, 295-310. http://dx.doi.org/10.1177/026327690007002017

Alexandru, F. (2012). The Context for Developing Intercultural Communicative Competence. Euromentor Journal, 3(1), 35-53.

Altrichter, H., Feldman, A., Posch, P., \& Somekh, B. (1993). Teachers Investigate Their Work: An introduction to the methods of action research. Clevendon: UK. Multilingual Matters.

Canagarajah, S. (1999). Resisting Linguistic Imperialism in English Teaching. Oxford: U.K. OUP.

Council of Europe. (2001). Common European framework of reference for languages. Retrieved from www.coe.int/t/dg4/linguistic/Source/Framework_ENG.pdf

Freeman, D. (1996). The 'unstudied problem': Research on teacher learning in language teaching. In D. Freeman, \& J. C. Richards (Eds.), Teacher Learning in Language Teaching. Cambridge: U.K. Cambridge Language Teaching Library.

Ju, F. (2013). Communicative Language Teaching (CLT): A Critical and Comparative Perspective. Theory and Practice in Language Studies, 3(9), 1579-1583. http://dx.doi.org/10.4304/tpls.3.9.1579-1583

Kemmis, S., \& Mc Taggart, R. (1988). The Action Research Reader (3rd ed.). Geelong, Victoria, Australia: Deakin University Press.

Kumaravadivelu, B. (2003). Beyond Methods: Macrostrategies for Language Teaching. Yale: USA. Yale University Press.

Kumaravadivelu, B. (2008). Cultural Globalization and Language Education. Yale: USA. Yale University Press.

Lewin, K. (1952). Group decision and social change. In G. E. Swanson, T. M. Newcomb, \& E. L. Hartley (Eds.), Readings in Psychology (pp.197-211). New York: Holt.

Lixian, J., \& Cortazzi, M. (1998). The culture the learner brings: a bridge or a barrier? In M. Byram, \& M. Fleming (Eds.), Language Learning in Intercultural Perspective. Cambridge Language Teaching Library. Cambridge: U.K. CUP.

Mills, G. E. (2003). Action Research: A guide for the teacher researcher (2nd ed.) Columbus, Ohio: USA. Merrill Prentice Hall.

Norton, B. (2000). Identity and Language Learning: Gender, Ethnicity and Educational Change. Essex: U.K. Pearson Education.

Ochs, E. (2002). Becoming a Speaker of Culture. In C. Kramsch (Ed.), Language acquisition and language socialization: Ecological perspectives. New York: USA. Continuum.

Stenhouse, L. (1979). Using Research Means Doing Research. In H. Dahl, A. Lysne, \& P. Rand (Eds.), A Spotlight on Educational Problems (pp. 71-82). Oslo: Norway. Oslo University Press.

Tudor, I. (2001). The Dynamics of the Language Classroom. Cambridge: U.K. Cambridge Language Teaching Library. CUP.

Van Lier, L. (2002). An Ecological-semiotic perspective on language and linguistics. In C. Kramsch (Ed.), Language acquisition and language socialization: Ecological perspectives. New York: USA. Continuum.

\section{Copyrights}

Copyright for this article is retained by the author(s), with first publication rights granted to the journal.

This is an open-access article distributed under the terms and conditions of the Creative Commons Attribution license (http://creativecommons.org/licenses/by/3.0/). 